\title{
Legal Dualism and the Bipolar State
}

\section{Challenges to Indigenous Human Rights in Brazil}

\author{
by \\ Cecilia MacDowell Santos \\ Translated by \\ Laurence Hallewell
}

The Brazilian state has contradictory laws, policies and practices with regard to the rights of indigenous peoples. Despite the adoption of a democratic Brazilian constitution in 1988 that incorporated a multicultural conception of indigenous rights and the subsequent ratification of new international norms of human rights for indigenous peoples, the practices of the courts and of the various sectors of the state reflect a legal cultural dualism and a "bipolar" state. The case of the Xucuru people sent to the Inter-American Commission on Human Rights shows the conflicts between legal and political cultures characterized, on one hand, by an individualistic and colonial approach to indigenous civil rights and, on the other hand, a collectivist and multicultural perspective on the human rights of indigenous peoples.

O Estado brasileiro possui leis, políticas e práticas contraditórias em relação aos direitos indígenas. Apesar da nova constituição democrática de 1988 ter incorporado uma concepção multicultural dos direitos indígenas e de o Estado ter ratificado normas internacionais de direitos humanos dos povos indígenas, as práticas dos tribunais e de vários setores do Estado refletem uma situação de dualismo da cultura jurídica e um Estado "bipolar." O caso do povo Xucuru encaminhado à Comissão Interamericana de Direitos Humanos demonstra os conflitos entre culturas jurídicas e políticas caracterizadas, de um lado, por uma abordagem individualista e colonial dos direitos civis dos indígenas, $e$, de outro lado, por uma perspectiva coletivista e multicultural dos direitos humanos dos povos indígenas.

Keywords: Indigenous peoples, Human rights, State, Violence, Brazil

Cecília MacDowell Santos is an associate professor of sociology at the University of San Francisco and a research associate of the Center for Social Studies at the University of Coimbra. She thanks the $L A P$ reviewers and César Augusto Baldi for their thoughtful comments on an earlier version of this article. She is especially grateful to the leaders of the Xucuru people and the activists of the Gabinete de Assessoria Jurídica às Organizações Populares, the Conselho Indigenista Missionário, and the Movimento Nacional de Direitos Humanos who granted her interviews and provided copies of legal documents relating to the Xucuru case. The ideas developed in this article have benefited from her participation in the ALICE Project "Strange Mirrors, Unsuspected Lessons: Leading Europe to a New Way of Sharing the World Experiences," coordinated by Boaventura de Sousa Santos at the Center for Social Studies at the University of Coimbra. Her research would not have been possible without the support of the Faculty Development Fund at the University of San Francisco. The translator, Laurence Hallewell, is a former Latin Americanist librarian at Columbia University. 
In late 2002 the Inter-American Commission on Human Rights (IACHR) received a request for a precautionary measure to safeguard the life of Marcos de Araújo, head of the Xucuru people of Ororubá, and that of his mother, Zenilda de Araújo, both of whom had been receiving death threats as a result of conflicts over the boundaries and legal recognition of the indigenous land in the municipio (county) of Pesqueira in Pernambuco state. The request was sent in the names of the Gabinete de Assessoria Jurídica às Organizações Populares (Juridical Assessment Committee for Citizens' Organizations-GAJOP), the regional office for the Northeast of the Movimento Nacional de Direitos Humanos (National Human Rights Movement-MNDH), and the Conselho Indigenista Missionário (Indigenous Missionary Council-CIMI). Around the same time, the first two of these petitioners also requested a precautionary measure to protect the lives of the lawyer involved, Elma Novais, and her children, then under threat from officers of the Military Police, who had murdered the son of the local lawyer in the município of Caruaru, also in Pernambuco. Both requests were granted (IACHR, 2002), but in fact protection could be provided only in the case of Novais. In the words of the GAJOP's lawyer at the time, Jayme Benvenuto Lima Jr. (interview, Recife, August 4, 2006), the protection given to Elma and her family

\begin{abstract}
was effected with great care over three years, with federal police guarding her $24 / 7$, both at her home and wherever else she wanted to go. ... She achieved the conviction and sentencing of three of the four accused and she is today no longer resident anywhere within Pernambuco state. I do not know where she is, nor does anyone else, because we are not allowed to, but we were assured by the defenders of human rights working with the Secretaria Especial de Direitos Humanos [Special Federal Secretariat of Human Rights-SEDH] that she had been taken from Caruaru somewhere else in Brazil.
\end{abstract}

In the case of the Xucuru, in contrast, the Federal Police had wanted to establish an office in the community, and this had been considered unacceptable. As Lima Jr. explained, "Their counterproposal, that the police mount a guard along the periphery and provide an escort whenever any Indian but particularly the head wished to travel outside the indigenous territory, was unacceptable to the police because the area to be covered was too large and it would have left them vulnerable themselves."

Although this and other cases sent to the IACHR are worthy of closer study, this paper has a more limited scope. Its intention is to reflect on the role of the state in the struggle of present-day indigenous peoples in Brazil for recognition of their human rights. As well as showing the conceptual limits to these rights and the legal and political obstacles they face, the Xucuru case offers an opportunity to reflect on how we understand the state and the idea of justice.

It would be absurd to try to secure the safety of the Xucuru by taking their head into hiding in another part of Brazil. The right to safety of Indians or indigenous peoples ${ }^{1}$ is an individual one, recognized as a civil right, but it cannot be separated from their collective right to their land, which is framed in terms of social, economic, and cultural rights. In effect, although the indivisibility of human rights is unchallengeable in contemporary legal doctrine, the courts' actual practice gives priority to an individualistic approach to human 
rights (Lima Jr., Gorenstein, and Hidaka, 2003; Piovesan, 2004). The practical relevance of this thesis becomes clear in the case of the human rights of indigenous peoples, a group that has been recognized worldwide as a collective subject in this regard.

An examination of the Xucuru case shows how difficult it is in Brazil for the human rights of indigenous peoples or the new multicultural approach to indigenous peoples on which such rights are based to be recognized. Guillermo de la Peña (2005) points out that indigenism emerged in nineteenth-century Latin America as a policy with the liberal and positivist objectives of assimilating the Indians and taking control of their lands. The new multicultural indigenism arose in the 1980s in the context of neoliberalism and the growth of indigenous movements in the region (Peña, 2005) — a context also marked by a return to democracy and increasing acceptance and formal ratification of international norms of human rights, including norms for the human rights of indigenous peoples. To what extent is this new multicultural indigenism being incorporated into Brazil's legal and political practices and attitudes? Which is the dominant norm, the individualistic and colonial understanding of Indians' civil rights or the collectivist and multicultural approach to the human rights of indigenous peoples?

According to Boaventura de Sousa Santos $(2003 ; 2006)$, political changes at the national level and globalization have both contributed to the appearance of new forms of legal pluralism at the subnational and supranational levels, with different legal traditions and practices operating with "relative autonomy" and, despite their frequent contradictions, increasingly impacting one another, creating "legal hybrids." At the same time, there has been increasing heterogeneity of state action both in the centers of the world capitalist system and on its periphery. As Santos (2006: 44) explains, "Under often contradictory pressures, the different sectors of state action are assuming such different logics of development and rhythms, causing disconnections and incongruities, that sometimes it is no longer possible to identify a coherent pattern of state action, a pattern common to all state sectors or fields of state actions." Santos (2006: 44) points out that this heterogeneity of state action is reflected

in the total breakdown of the already shaky unity of state legality, each [component] of which operates with relative autonomy. In extreme cases such autonomy may lead to the formation of multiple microstates existing inside the same state. I call this political formation the heterogeneous state. . . . It is characterized by the uncontrolled coexistence of starkly different political cultures and regulatory logics in different sectors (e.g., in economic policies and family or religious policies) or levels (local, regional, and national) of state action.

Drawing on the data I have gathered about the $\mathrm{Xucuru}{ }^{2}$ and on the laws and policies about indigenous rights in Brazil, I argue that there is a dualism in the politico-legal culture in this regard: on the one hand we encounter a colonial and individualistic conception of their civil rights, embedded in some of the country's laws and the behavior of state agents, while on the other some norms and some sectors of the state are introducing a multicultural and collectivist approach to those rights. The Brazilian state can therefore be characterized as "heterogeneous" and particularly as what I call a "bipolar" state. To demonstrate my argument, I shall first present examples of laws and policies that 
embody an individualistic approach to indigenous rights whose origins go back to the colonial period. I will then move on to discuss the legal dualism that has emerged since the democratization process that started in the 1980s with the end of the military dictatorship that lasted from 1964 to 1985.

\section{THE COLONIAL INHERITANCE IN INDIGENOUS CIVIL RIGHTS: GUARDIANSHIP, LAND EXPROPRIATION, AND ASSIMILATION}

Brazilian history is marked by what Warren (2001) calls "Indian exorcism" the physical and cultural extermination of the indigenous peoples by mass killings by the army, enslavement, expropriation of their land, religious missions to convert them to Christianity, and policies aimed at their assimilation. In the colonial period, the European settlers invaded their lands, killed many of them off, and enslaved the others (Melatti, 2007; Perrone-Moisés, 1998; Warren, 2001). The Portuguese colonizers reached the Xucuru territories in what is now known as Ororubá in 1654. We are told that the proprietors of these lands, granted to them by the crown, invaded them, used them as cattle pasture, and enslaved their inhabitants. Some of the latter resisted, forming the so-called Confederation of the Cariri, but were massacred by the settlers after a war that lasted from 1692 to 1696 (Almeida, 1997: 17-18).

Government documents starting from Independence in 1822 speak of the "expectation of some great plan to civilize the Indians" (Cunha, 1998a: 138). Indigenous territories were gradually transformed into ordinary municípios and the villages within them into parts of the Brazilian nation (Mendes Júnior, 1988 [1912]: 47). Their inhabitants were driven into the bush and formally reclassified by the government as caboclos (hillbillies), losing all rights to use the common land of the former lands (Arruti, 2006: 51). The republic that was proclaimed in 1889 continued the assimilation of the indigenous peoples on positivist and evolutionist principles of "progress" (Melatti, 2007: 252). Its settlement program was one of national expansion and integration of the indigenous peoples into the national workforce. To achieve this, in 1910 the federal government set up the Serviço de Proteção aos Índios e Localização de Trabalhadores Nacionais (Indian Protection and National Manpower Distribution ServiceSPI). The creation of this agency signified the establishment of an official indigenous policy and the apparatus to carry it out (Lima, 1998). In 1944 an official of the SPI submitted the first report on the Xucuru of Ororubá, stating that there were some 2,191 indigenous people there suffering persecution and threats from the police of the town of Pesqueira (Almeida, 1997: 22).

The idea of a civil capacity and degrees of guardianship reflecting the stage of civilization each indigenous group had reached was included in the Civil Code of 1916, which identified the silvicolas (Indians) as "incapable in respect to certain legal acts" (Article 147, Paragraph 1) or "unable to exercise them" (Article 6, Clause 3) and made them subject to "guardianship, defined in special laws and regulations, to be eased or lifted as they became adapted to Brazilian civilization" (Article 6). The 2002 Civil Code does not declare Indians incapable of certain acts, but it does allow their capacity to be regulated (Article 4) by the Indian Statute (Estatuto do Índio, Law 6,001 of December 19, 1973) 
enacted during the military regime and still in effect by the time this paper was written (April 2014), which incorporates the 1916 provisions with regard to guardianship by the state.

At the end of the nineteenth century there was debate whether the ownership of indigenous lands should be subject to the special legal situation known as indigenato (the regime of land possession based on the traditional land occupation by indigenous peoples) or to normal civil law (based on land title of property granted by the state). The jurist João Mendes Júnior (1988 [1912]: 55) maintained that the right to indigenous lands was a "preexisting right" (prior to colonialism) based on the traditional land occupation by indigenous peoples and was independent of any legal act. The 1891 Constitution had no specific chapter on indigenous rights but bestowed on the individual states dominion over unoccupied or vacant land and the power to recognize titles of ownership subject to the civil law. From then on, states frequently declared indigenous lands to be unoccupied and, when disputes arose between settlers and the indigenous peoples, began requiring the latter to register their lands or show legal proof of ownership (Mendes Júnior, 1988 [1912]). In the process of demarcating the lands of the village of Cimbres, where the Xucuru people of Ororubá lived, for example, the local ranchers registered these lands in their own names as occupants (Almeida, 1997: 20). The 1934 Constitution established that indigenous lands belonged to the federal government and that the Indians had a right to such lands as they already effectively occupied. It did not, however, recognize any preexisting right of land based on indigenous traditional occupancy, and by that time the indigenous peoples in the Northeast did not effectively occupy their land (Arruti, 2006).

The military government abolished the SPI in 1967, replacing it with the Fundação Nacional do Índio (National Indian Foundation-FUNAI), an agency linked to the Justice Ministry (Law 5,371 of 1967). Until 2003 the law regulating the FUNAI charged it with "exercising, in the name of the Federal Union, guardianship of Indians and of indigenous communities not yet wholly integrated into the nation" (Article 2, Clause 1, Annex 1, Decree 4,646 of 2003). This assimilationist language was changed in 2009 with the promulgation of Decree 7,056 , which charged the FUNAI with the duty to "exercise, in the name of the Union, the protection of indigenous peoples and the promotion of their rights" (Article 2, Clause 1, Annex 1). Decree 7,778 of 2012 kept this new language of "protection of the indigenous peoples" unchanged, giving the FUNAI the objective of promoting "studies to identify, delimit, demarcate, and formally enter in the land registry the lands traditionally occupied by the indigenous peoples" (Article 4, Annex 1, Decree 7,778 of 2012). The Indian Statute regulates the demarcation of "lands occupied or inhabited by the forest Indians" and of "areas reserved according to the law" (Article 17). These lands are the inalienable property of the federal government, which safeguards the indigenous peoples' occupation of them in perpetuity.

The FUNAI has inherited colonial assumptions and has never been given enough resources to carry out its legal duties (Oliveira and Almeida, 1998). During the dictatorship it was under the military government's direct control, and anthropologists or other professionals deemed sympathetic to the cause of the indigenous peoples were regularly removed from it. Under the military 
regime, the FUNAI facilitated government intervention in indigenous lands in favor of the economic interests of the local and international elites. One example of this is what happened in the territory of the Yanomami in northern Amazonia. There the government authorized exploiting the area's mineral wealth and building the BR-210 federal highway, which cut right through the territory of the Yanomami and other indigenous peoples, doing great damage to their communities and to the environment (Rabben, 2004). In 1980 representatives of North American nongovernmental organizations such as the Indian Law Resource Center and the American Anthropological Association denounced the situation to the IACHR, which in those days very seldom opposed Latin American dictatorships. Surprisingly, in 1985 the IACHR recognized that several articles of the 1948 American Declaration of the Rights and Duties of Man had been violated and recommended that the Brazilian state protect its indigenous population and demarcate its territory (IACHR, 1985). The process of demarcation was at last completed in 1992. This case was a pioneer decision by the IACHR with regard to the rights of the indigenous peoples and was the second case in which the commission recognized Brazil's responsibility for human rights violations committed by the state during the dictatorship (Santos, 2007).

\section{EXPANDING THE STRUGGLE FOR INDIGENOUS HUMAN RIGHTS IN LATIN AMERICA}

In the 1980s and 1990s, the new situation created by the growth of movements for indigenous rights and for a return to political democracy opened the way for change in the laws and policies relating to the indigenous peoples in the various countries of Latin America, which began to move from ideas of assimilation to the recognition, at least rhetorically, of ethnic differences and cultural diversity (Jackson and Warren, 2005; Sieder, 2002; Stavenhagen, 2002). In response to indigenous demands for collective land rights, self-determination, political participation, ethnic identity, and cultural diversity, constitutional reform began to recognize in principle "the multi-ethnic and pluricultural nature of those societies" (Sieder, 2002: 4; see also Van Cott, 2002) and a new "multicultural indigenism" (Peña, 2005).

Ever since the 1980s, the indigenous peoples of Latin America have been demanding recognition of their collective human rights defined in historical, ethnic, and cultural terms. ${ }^{3}$ The idea of "group" human rights rejects the supremacy of civil and political rights, characterized as individual, over economic, social, and cultural rights, characterized as collective (Piovesan, 2004). The thesis of the indivisibility of these rights predominated in the Human Rights Conference organized by the UN in Vienna in 1993 and in the commemorations of the fiftieth anniversary of the Universal Declaration of Human Rights in 1998 (Donnelly, 2002). In 1989 the International Labor Organization adopted the multicultural and collectivist approach to indigenous rights with its Convention 169 on indigenous and tribal peoples. Of the 22 states that had ratified this convention by the time this paper was written (April 2014), over half of the signatories were countries of Latin America (ILO, 2014). In 2007, after 20 years of discussion, the UN 
adopted the Declaration on the Rights of Indigenous Peoples, approved by an absolute majority of 144 states. The IACHR and the Inter-American Court of Human Rights (IACtHR) have been developing a jurisprudence that establishes "a model for new approaches on the part of international justice in the treatment of rights that titularly correspond, collectively, to indigenous communities in virtue of their ethnic and cultural particularities in relation to society as a whole" (Melo, 2006: 31).

The literature on indigenous movements in Latin America has questioned the extent to which this new multicultural indigenism represents a new type of citizenship and whether it can have any transformational potential in the face of the neoliberalism that dominates economic policies and hinders the implementation of social and cultural policies (Brysk, 2002; Figueroa, 2006; Hale, 2005; Jackson and Warren, 2005; Laurie, Andolina, and Radcliffe, 2002; Peña, 2005; Rodríguez-Garavito and Arenas, 2005). As Jackson and Warren (2005: 566) have pointed out, apart from the ambiguities about constitutional standards and in peace agreements and state-mediated transition policies, the power structures that sustained authoritarian regimes and racial and ethnic discrimination are still in place. In this situation, the main objective of the organizations of indigenous peoples continues to be achieving the recognition of collective land rights. In Brazil, among the problems of implementing the new constitutional provisions on the rights of indigenous peoples from a multicultural perspective is the prevalence of a legal and political culture of indigenism that is still shaped by an individualist and colonial outlook.

\section{LEGAL DUALISM UNDER THE 1988 CONSTITUTION: BETWEEN GUARDIANSHIP AND MULTICULTURAL INDIGENISM}

In Brazil, the proportion of the population that identifies itself as indigenous is less than 0.5 percent, ${ }^{4}$ but mass protests by indigenous peoples during the 1980s had some important legal successes. The CIMI was set up in 1972 with the aim, based on liberation theology and human rights, of securing the return of indigenous peoples' lands, and at the end of the 1970s various secular NGOs were created to support the indigenous rights struggles (Arruti, 2006). Mass protests by indigenous organizations while the Constituent Assembly was writing a new constitution in 1988 managed to get many of their demands included in the document. As José Roberto Santos, a missionary with the CIMI in Pernambuco, recalled (interview, Recife, August 4, 2006), "Chicão [Francisco de Assis Araújo, head of the Xucuru from 1986 to 1998] liked to say that the chapter of the constitution and Articles 231 and 232 [on the Indians] are the fruit of the blood, sweat, and tears of the indigenous peoples."

The 1988 Constitution recognizes "the Indians' social organization, customs, languages, beliefs and traditions and their preexistent (original) rights on the lands that they have traditionally occupied, and the responsibility of the Union to demarcate them, protect them and ensure that their ownership of all their goods and chattels be respected" (Article 231, emphasis added). These lands have remained the property of the federal government, although they 
are described as being in the "permanent possession" of the indigenous peoples. This has been interpreted by constitutional lawyers (Neto, 1993; Silva, 1998) and anthropologists (Cunha, 1988b [1912]; Oliveira, 1998) as constitutional recognition of the indigenato and the collective rights of indigenous peoples to possession of their lands and their sociocultural organization.

Despite the constitution's recognition of a new multicultural indigenism, the Indian Statute of 1973 has remained in force. In the early 1990s there were bills (Numbers 2,057 and 2,160 of 1991 and 2,619 of 1992) designed to institute a new "indigenous peoples' statute" more compatible with the constitution, but progress on them was halted by the approval in 1994 of an alternative solution proposed by the Partido Social Democrático Brasileiro (Brazilian Social Democratic Party-PSDB) and by attempts by the mining companies and representatives of agri-business to break the legislation up by sector of the economy. As Saulo Feitosa, a former vice president of the CIMI, declared (interview, Brasília, August 22, 2006),
The big mining companies and the agri-business sector are trying to break the statute up: to submit one bill concerning mining and another on demarcating their lands, taking each on its own, because that way the Indians will not be able to affect the outcome with public demonstrations. Separate bills will be open to lobbying by the really big lobbies. Our task is to avoid getting any of these bills approved. I believe that there are 132 of them under discussion [in Congress].

The 1988 Constitution established that indigenous lands were to be demarcated by the government "within five years of the promulgation of the Constitution" (Article 67), but nothing was in fact done during this period and many indigenous groups are still fighting to get their lands demarcated. ${ }^{5}$ The administrative procedure involved in such demarcation is complicated and slow. It has five phases: (1) identification of boundaries (done under the FUNAI's direction by a technical group of anthropologists and other professionals chosen by it), (2) the declaration, embodied in a Justice Ministry directive, of the boundaries of such land, (3) the actual physical demarcation, carried out by the FUNAI, (4) approval by a decree of the office of the president, and (5) registration by the FUNAI with the court district in which the land is located and with the Finance Ministry's Department of Federal Property.

Although the constitution requires indigenous land to be demarcated regardless of whether the indigenous people are in effective occupation of it, the actual situation varies from one part of the country to another. As Saulo Feitosa has explained (interview, Brasília, August 22, 2006):

There are situations, mostly in the North of Brazil, where the Indians are in occupation but have suffered invasion and expulsion. In cases in the Northeast and even in the South and Southeast, most indigenous lands were invaded many years ago. This was the situation with the Xucuru. But generally in the Northeast it is the Indians who have asserted their possession. The government has begun to take action to have land demarcated only after the Indians have clashed directly with those invading their lands and managed to take them back. 
Despite the FUNAI's limited political influence and power, the representatives in Congress of the big rural landowners and of agri-business have been trying since 2000 to get legislative power over the process of demarcation. A proposal currently going through the Chamber of Deputies calls for a constitutional amendment that would give the Congress the sole prerogative of approving the demarcation of land occupied by indigenous peoples and ratifying existing demarcations, even those already approved by the executive (Câmara dos Deputados, 2000).

The 1988 Constitution paved the way for the incorporation of international standards and norms of human rights when it established that, in its foreign relations, the state must adopt the principle that "human rights take overriding precedence" (Article 4, Paragraph 2). Nevertheless, Brazil, in contrast to other countries of Latin America, took more than 10 years to ratify Convention 169, accomplishing this only in 2002, the last year of the Cardoso presidency (DecreeLaw 143 of June 20, 2002). ${ }^{6}$ The Cardoso government had created the first National Program of Human Rights in 1996 (Decree 1,094 of 1996). This program set up various targets, including formulating and implementing a new policy toward indigenous peoples "to replace assimilationist policies and those treating Indians as in need of handouts and guardianship," "to support revision of the Indian Statute," and "to provide the FUNAI with sufficient resources to carry out its mission of defending the rights of the indigenous societies, particularly in the process of demarcating their lands" (Presidência da República, 1996: 31-33). To put this program into effect, Cardoso created, in 1997, a national department of human rights, but it became a major agency of the state only during the first administration of President Luiz Inácio "Lula" da Silva (2003-2006), when it was named the Secretaria Especial de Direitos Humanos (Special Secretariat of Human Rights_SEDH) by Law 10,683 of 2003.

In legal and political practices, guaranteeing the human rights of indigenous peoples has met positive reactions in some sectors of the state and negative ones in others. The case of the Belo Monte hydroelectric plant on the Xingu River is a good example. Approved by Congress in 2005, the project has produced legal disputes over whether the local indigenous peoples affected had the right to be consulted beforehand. The Attorney General's office and the Supreme Court have decided in favor of going ahead with construction despite there having been no such consultation, but the indigenous community and its allies have had the support of the First Circuit District Court, the IACHR, and the UN, which have declared that the work should stop until such consultation has occurred. In 2011 the IACHR's decision provoked a strong reaction by the government under the presidency of Dilma Rousseff (2011-2014; reelected in 2014) and led to a crisis in the Organization of American States (Reis, 2013).

\section{THE XUCURU CASE: VIOLENCE AND DEADLOCK IN PROTECTING THE HUMAN RIGHTS OF INDIGENOUS PEOPLES}

The history of the struggles over the rights to land and security of the Xucuru is like the Belo Monte case in that both can be understood as conflicts between different sectors and levels of administration of the state and of justice. With a 
population of roughly 8,500 inhabitants, the Xucuru live in 23 "villages" on some 27,555 hectares $(68,088$ acres) of demarcated territory in the former Cimbres municipality. Their struggle to have their occupancy of their land and their distinct culture recognized began to intensify in the mid-1970s, ${ }^{7}$ and in the 1980s they played a leading role in the mobilizations and protests of the indigenous peoples of the Northeast and helped take their demands to the federal government in Brasília (Almeida, 1997; Rabben, 2004). Since the 1970s the Xucuru have been able to count on the support of the CIMI and other NGOs such as the Centro de Cultura Luiz Freire and the GAJOP. Against the practices of the Federal Police, the Public Prosecutor's Office, and the federal courts, which have sided with the local big landowners, the Xucuru have also had official support at the federal level from the SEDH and the FUNAI and at the state level from Eduardo Campos, two-term governor of Pernambuco who died in an airplane accident while campaigning for the 2014 presidential elections. Internationally, they have received support from Amnesty International, the American Anthropological Association, and the IACHR.

The process of identifying and demarcating the lands of the Xucuru people was begun in 1989 and completed in 2005. Besides taking a long time, this process involved considerable violence. Five Indians were assassinated, among them Chicão and a FUNAI lawyer who had been active in defending the rights of indigenous peoples. In 1988 the federal government had given the go-ahead to a cattle-raising project benefiting the rancher Otávio Carneiro Leão. Led by Chicão and by their shaman, the Indians held demonstrations and petitioned the Public Prosecutor to set up a public civil inquiry into the exclusion of the FUNAI from the demarcation of the Xucuru's lands. The commission of inquiry that was established put pressure on the FUNAI to set up a working group in 1989 that began identifying and demarcating the lands, finding 282 properties to have been occupied by non-Indians, many of them big landowners and relatives of politicians (Almeida, 1997: 25). These properties accounted for 56.2 percent of the land, and their occupiers were to be removed and paid compensation for any improvements they had carried out. In 1992 the Justice Ministry issued Ordinance 259 recognizing the area demarcated, and this provoked tension. The illegal occupiers had not yet been removed, so the Xucuru, led by Chicão, began a series of land "recoveries" (retomadas). ${ }^{8}$ At this point the shaman's son was murdered. The physical demarcation was completed in 1995, and that year witnessed the assassination of the FUNAI lawyer Geraldo Rolim.

In 1996 President Fernando Henrique Cardoso signed Decree 1,775 of 1996, which changed the administrative procedure for demarcating indigenous land, introducing the "principle of contradictions." This principle referred to the right of defendants in legal actions to defend themselves (which of course they already had), and it created the opportunity for further delay in implementing demarcations and led to an increase in acts of violence against indigenous groups. ${ }^{9}$ In some cases the decree was used to put a legal halt to a demarcation in progress. It was also used to reduce the area of lands under indigenous occupancy (Feitosa, 2006: 13). ${ }^{10}$

"At this period," Saulo Feitosa explained (interview, Brasília, August 22, 2006), "272 pleas were entered contesting demarcations of Xucuru lands, 
which means you had the FUNAI working under the pressure of 272 illegal occupiers." Those making such pleas included the Prefecture of Fishing, the municipal council, and local big landowners. When the ministry rejected all the pleas as lacking justification, the landowners sought an injunction in the federal appeals court. This was granted in May 1997 and required the opening of a new opportunity for the submission of objections. The minister of justice, José Gregori, accepted a FUNAI report and ruled that the objections had no legal value, but the delay caused by the court's action led to more tension and further violence against the Xucuru. Although the FUNAI had by now demarcated all the Xucuru lands, new occupiers had invaded them, including many members of ranchers' families, and there had also been sales and transfers of these lands. The Xucuru responded with actions of "recovery," intensifying the conflict. Chicão was assassinated in May 1998. As his widow, Zenilda de Araújo, recalled (interview, São Jose reservation, February 29, 2008), "From the moment he was appointed cacique, the ranchers had been threatening him, but he was not intimidated. On one occasion he denounced one of those who had threatened him and asked the court to afford him police protection, but the court would not take him seriously."

The wave of violence that the conflicts over land had engendered went on after Chicão's death. Attempts to end the indigenous protests and demonstrations took on a new nature, including criminalizing, dividing, and co-opting members of the Xucuru community. The Federal Police and the Public Prosecutor's Office, in a very public alliance with the leaders of the local economy, introduced a story of internal conflict between rival indigenous groups into their official investigation into the death of Chicão and the murders of other Indians later on. As Zenilda de Araújo explained, "After they had killed Chicão, they started to go after me and my son, Marquinho [Marcos de Araújo]. Then, for five whole years, I was persecuted by the justice system as one of the suspects in the murder." The Federal Police in Pernambuco came up with the theory of a crime of passion.

In April 2001 President Cardoso signed the decree ratifying the demarcation of the Xucuru's territory. In May 2001 the official in charge of the land registry of the court district of Pesqueira started a legal action claiming irregularities in the demarcation decree, which delayed the entry until August 2005. In July 2001, just two months after the FUNAI had tried to register the Xucuru territory, their community leader, Pé de Serra do Oiti, was assassinated. Marcos Cotrim, the Federal Police official appointed to investigate the case, accepted the idea that this was an internal quarrel among the Indians and indicted two of them, one being the Xucuru cacique's deputy. The same supposition of an internal indigenous conflict was adopted when the police were investigating a fire and the resulting damage that had occurred when the community had rioted in protest of the assassination of two Indians who were protecting Marcos de Araújo against an assassination attempt on Xucuru land in February 2003. In the course of their investigation into the revolt, the Federal Police and the Public Prosecutor's Office in Pernambuco set up seven police inquiries and began criminal proceedings against 35 Indians, including several of their leaders and the intended victim of the assassination attempt, accusing them of having been responsible for stirring up the community. 
I had the chance to attend a federal court hearing in Caruaru on August 3, 2006, and to see how the judge and the representatives of the Public Prosecutor's Office pressured the Indians. The effects of my being there were reported to the then vice president of the CIMI in Brasília, Saulo Feitosa, who commented on the hearing as follows (interview, Brasília, August 22, 2006):

In Pernambuco we have always been seriously concerned with the procedure adopted by the judges, whether judges on the benches of federal courts, judges working for the Public Prosecutor's Office, or judges of the first instance, and by the Federal Police. We realize that while you were there at the audience in Caruaru, the judge adopted a more civilized posture, and the Indians did not feel under quite so much pressure as they usually suffered, but his manner of posing questions was always intimidating, which inhibited the Indians or forced them to give their answers the way he wanted them given.

In 2000, the CIMI and the GAJOP began to consider submitting the Xucuru case to the IACHR in an attempt to speed up the process of demarcation and protect the lives of Araújo and his mother (Marcos de Araújo, interview, Ororubá, February 29, 2008). Araújo had become the new head of the Xucuru in January 2000 and had immediately begun to receive death threats from local ranchers. At that time 70 percent of the Xucuru land in the area was occupied by squatters and ranchers making business use of it, and the Indians had begun taking it back. The need for protection of the pair of them was also presented to the UN and to Amnesty International. In October 2002, as we have seen, the case was submitted to the IACHR, and the petition was immediately granted. ${ }^{11}$ The $\mathrm{SEDH}$ illustrated the lack of coherent government in contemporary Brazil by showing a readiness to negotiate, even though it had not at first recognized that effective protection as suggested by the Federal Police would be impossible. In contrast with the case of the lawyer Elma Novais, whereas the lawyer could be protected as an individual and relocated, the death threats made against the indigenous leaders arose precisely from their status as persons subject to the law on indigenous peoples, a status defined by their collective ethnic identity and rooted in an indigenous territory. This collective conception of the human rights of indigenous peoples was a challenge that even the GAJOP had not understood when it began negotiating with the Federal Police on protection for the Xucuru leaders (Jayme Benvenuto Lima Jr., interview, Coimbra, July 4, 2009).

The SEDH was the agency that best understood the need for a different way to protect the Xucuru leadership. In February 2003 it submitted its second report on the case to the IACHR, declaring that "the protection offered by the Federal Police showed how very complex its way of working was, involving as it did relating the autonomy guaranteed to the indigenous communities by the constitution to the powers and responsibilities of the Federal Police." In other words, the police had not absorbed the new multicultural indigenism provided for in the constitution and the National Human Rights Program. The SEDH also recognized that the difficulty lay in the powerful influence of the "local ranchers who were opposed to the process of effectively demarcating the Indians' lands." Finally, it recognized that "the relationship between the Xucuru community and the local representatives in Pernambuco state of both the Public Prosecutor and the regional superintendency of the Federal Police had become 
quite antagonistic since the still inconclusive investigations into the murder of the Indian Chico Quelê in 2001" (Ministério da Justiça and SEDH, 2003).

The federal Attorney General's Office in Pernambuco initiated an administrative process, but the local Public Prosecutor's Office decided to shelve this in 2007 on the ground that "those being offered the benefit of such protection had not been sufficiently cooperative for it to become effective." By March 2008 the non-Indian occupiers had been expelled from most indigenous lands and paid appropriate compensation, but the death threats to the Xucuru leaders continued. In mid-2007 one of those responsible for the attempt on the life of Marcos de Araújo had been released from custody, only to renew his threats. Araújo appealed to the governor, Eduardo Campos, and with support from both the governor and Amnesty International his case was taken up in March 2008 by the then created State Program of Protection of Defenders of Human Rights, which secured him the protection of two indigenous military policemen whom he was ready to trust. As was the lawyer Elma Novais, he was given protection as an individual, but it was provided by the state's Military Police instead of by the Federal Police. Although his life was now under police protection, his safety continued to be treated from the perspective of individual human rights. He was being afforded protection because of his activism as a defender of human rights and not as a leader of indigenous people.

In 2009 Araújo was sentenced to 10.5 years' detention for arson and the consequent damage in connection with the community's reaction to the 2003 assassination attempt. Thanks to local and international protests of this outrage, including a letter from the American Anthropological Association (2009), the Fifth Circuit Court reduced the punishment on appeal to 2 years' community service. Given the police protection Araújo had previously obtained, this result was yet another example of the bipolar behavior of the state in the field of indigenous peoples' human rights.

\section{CONCLUSIONS}

The disparate ways in which the state acts and reacts in Brazil could lead to a situation of extreme "internal (within the state) legal pluralism." According to Santos (2003: 63), "internal legal pluralism" refers to a "socio-legal condition that sees itself as official, formal, modern and national but in which we find, in its practical domestic application, the presence of some or all the poles of dichotomies: of the informal, the traditional, the local, or the global." This situation tends to be provoked by the presence of at least one of the following factors: "disjunction between the political and the administrative control of the territory and its inhabitants; a failure of the diverse political and legal cultures inside the state and the official law to bed down together; great political and institutional instability, produced by manifold breaches following each other in quick succession; and an acute crisis of the state, which comes close to imploding" (64). On top of these factors, "not all forms of state heterogeneity presuppose a situation of internal legal pluralism. This requires the coexistence of different concepts of regulation carried out by different state agencies that have very little interaction or communication" (56). 
Analysis of the Xucuru case allows us to identify two politico-legal cultures in conflict within the state, but the branches of the state that act in the field of indigenous rights are in communication with each other and, depending on the context and on the public forces at the local, national, or international level, may embrace one politico-legal culture or the other in their relations with indigenous peoples. In this sense, the situation does not seem to qualify as internal legal pluralism, even though the state presents traces of heterogeneity in the way it acts politically, administratively, and judicially.

In the Xucuru case, the actions of a single sector of the state such as the Public Prosecutor's office or the Federal Police are not characterized by the superimposition of different legal and political cultures with regard to indigenous peoples. On the contrary, one finds in these sectors the hegemony of a colonial and individualistic understanding of indigenous rights, backed up by laws enacted during the military dictatorship that bear the imprint of the colonial and authoritarian tradition in Brazil's political and social structures. At the same time, we should not generalize from what has been happening to the Xucuru and assert that the Public Prosecutor's office acts in the same way in every state in Brazil. Nor should we conclude from this case that the conflict between different state agencies is simply a matter of differences between the local and the national level. In the realm of executive power at both the federal and the state level we find sectors that embrace a multicultural and collectivist perspective toward the rights of indigenous peoples, with the SEDH and the state of Pernambuco as examples, whereas the Attorney General's Office, at the federal level, has adopted positions openly opposed to indigenous peoples' rights (CIMI, 2012: 9).

It would be worthwhile to compare the actions of government agencies at different levels_-state and regional-and between Brazil and other countries, looking at the social and politico-legal conditions that may generate different degrees of heterogeneity in policies and state action. This sort of research would be particularly important for understanding obstacles to ensuring the human rights of indigenous peoples and other oppressed social groups. The Xucuru case shows that constitutional recognition of indigenous human rights and a multicultural and collectivist perspective does not eliminate the legal and political obstacles to implementing those rights. In Latin America, norms are seldom backed up by laws below the level of the constitution to regulate their application (Carbonell, 2003). At the same time, the legalization of indigenous human rights is not enough to transform social structures and unequal power relationships. As Molinero (2006: 175) points out, “This kind of recognition of indigenous rights does not mean a (re)constitution of the state, a revision of the structures that consolidate and perpetuate discrimination and subordination; on the contrary, it implies an effort to keep indigenous peoples' identities tied to a structure that is incapable of recognizing pluralism and multiculturalism."

\section{NOTES}

1. The term indigena is used by social scientists in Latin America to replace the term indio (Indian), with its colonial origin (Peña, 2005). The Xucuru of Ororubá call themselves índios but also designate their struggle, their nation, and their rights as indigenas (see also Almeida, 1997). 
2. The data were gathered in August 2006, February and March 2008, and July 2009, and updated in April 2014. In Brasília I interviewed the vice president of the CIMI and one of its lawyers, as well as two lawyers of the SEDH. In Recife I interviewed three lawyers from the GAJOP, a missionary and three lawyers from the CIMI, and the representative of the Northeast region of the MNDH. In Caruaru I interviewed indigenous leaders at a criminal trial in the city's federal court. In Pesqueira I visited two villages of Xucuru people of Ororubá, interviewing Marcos de Araújo and his mother.

3. There has been criticism with different motives and in different contexts of the idea of the universality of human rights, which is said to have failed to take into account local conditions or cultural diversity (An-Na'im, 2002).

4. According to the Instituto Brasileiro de Geografia e Estatística census of 2010, some 896,917 inhabitants stated that they were indigenas, the equivalent of 0.47 percent of the total population (IBGE, 2013).

5. According to the CIMI, as of December 2013 some 359 pieces of indigenous peoples' lands had been registered out of a total of 1,047, while 359 awaited processing and had not yet even been identified (CIMI, 2013: 31).

6. Brazil was also one of the last to recognize the jurisdiction of the IACHR, in 1998 (Santos, 2007).

7. Until the 1980s indigenous peoples were believed to be extinct in the Northeast (Dantas, Sampaio, and Carvalho, 1998). The first IBGE census to include the question "color" was that of 1990. Thanks to the resistance of the indigenous peoples and to the legal changes that resulted from the 1988 Constitution, more and more individuals in the Northeast have begun to identify themselves as indigenas through a process that French (2009) has called "legalization of the indigenous identity" in this region. In its 2010 census the IBGE shows the Northeast as the region with the second-largest proportion of Indians in its population (25.9 percent), second only to the North, with 38.2 percent (IBGE, 2013).

8. Basing their claim on the thesis of their original indigenous right to possession of their lands, the Indians called these actions "recoveries," making a distinction between them and the "occupations" carried out by the Movimento dos Sem-Terra (Landless Workers' MovementMST), which are legitimized in terms of the constitutional provision establishing the social function of property ownership.

9. The CIMI states that 287 Indians were assassinated between 1995 and 2005. During the eight years of the Cardoso government, 165 Indians were assassinated, or an average of around 20 a year. In 2003-2005, the first two years of the Lula government, the yearly average was double that under Cardoso. In the first three years of the Dilma government the number of assassinations of Indians was 54. Between 2003 and 2013, at least 616 Indians are reported to have been assassinated (CIMI, 2013: 49).

10. The CIMI has pointed out that, from the end of the military regime in 1985 until 2013, the average number of indigenous lands registered was greatest during the presidential term of Fernando Collor de Melo (1990-1992), 56 per year, followed by the two terms of Fernando Henrique Cardoso (1995-2002), with an average of 18 per year. During Lula's two terms (20032010) the yearly average dropped to 10 , while in the first three years of the Dilma Rousseff government (2010-2014) it fell further, to 3.6 percent (CIMI, 2013: 31).

11. The decision was not published until 2009 (IACHR, 2009).

\section{REFERENCES}

Almeida, Eliene Amorim de

1997 Xucuru, filhos da mãe natureza: Uma história de resistência e luta. Olinda: Centro de Cultura Luiz Freire, Projeto Xukuru.

American Anthropological Association

2009 "Xukuru letter." http://www.aaanet.org/cmtes/cfhr/xukuru-letter.cfm (accessed April $29,2014)$.

An-Na'im, Abdullahi A. (ed.).

2002 Cultural Transformation and Human Rights in Africa. London: Zed Books. 
Arruti, José Maurício

2006 "Etnogêneses indígenas," pp. 50-54 in Beto Ricardo and Fany Ricardo (eds.), Povos indígenas no Brasil: 2001-2005. São Paulo: Instituto Socioambiental.

Brysk, Alison

2002 "Introduction: Transnational threats and opportunities," pp. 1-16 in Alison Brysk (ed.), Globalization and Human Rights. Berkeley, Los Angeles, and London: University of California Press.

Câmara dos Deputados

2000 "PEC 215/2000 - Proposta de Emenda à Constituição." http:/ /imagem.camara.gov.br/ Imagem/d/pdf/DCD19ABR2000.pdf\#page=69 (accessed July 31, 2015).

Carbonell, Miguel

2003 “La constitucionalización de los derechos indígenas en América Latina: una aproximación teórica." Boletín Mexicano de Derecho Comparado 36: 839-861.

CIMI (Conselho Indigenista Missionário)

2012 Violência contra os povos indígenas no Brasil: Dados de 2012. Brasília: Conselho Indigenista Missionário.

2013 Violência contra os povos indígenas no Brasil: Dados de 2013. Brasília: Conselho Indigenista Missionário.

Cunha, Manuela Carneiro da

1998a "Política indigenista no século XIX," pp. 133-154 in Manuela Carneiro da Cunha (ed.), História dos Índios no Brasil. 2d edition. São Paulo: Companhia das Letras/Secretaria Municipal de Cultura, FAPESP.

1988b (1912) "Apresentação," in João Mendes Júnior (ed.), Os indigenas do Brazil, seus direitos individuaes e politicos. Facsimile edition. São Paulo: Typ. Hennies Irmãos.

Dantas, Beatriz G., José Augusto L. Sampaio, and Maria Rosário G. de Carvalho 1998 "Os povos indígenas no Nordeste brasileiro: Um esboço histórico," pp. 432-556 in Manuela Carneiro da Cunha (ed.), História dos Índios no Brasil. 2d edition. São Paulo: Companhia das Letras/Secretaria Municipal de Cultura, FAPESP.

Donnelly, Jack 2002 "Human rights, globalizing flows, and state power," pp. 226-241 in Alison Brysk (ed.), Globalization and Human Rights. Berkeley: University of California Press.

Feitosa, Saulo 2006 “A década da violência," pp. 13-14 in Conselho Indigenista Missionário (ed.), A violência contra os povos indígenas no Brasil: Relatório 2003-2005. Brasília: Conselho Indigenista Missionário.

Figueroa, Isabela 2006 "Povos indígenas versus petrolíferas: controle constitucional na resistência." Sur: Revista Internacional de Direitos Humanos 4 (3): 49-79.

French, Jan Hoffman 2009 Legalizing Identities: Becoming Black or Indian in Brazil's Northeast. Chapel Hill: University of North Carolina Press.

Hale, Charles R.

2005 "Neoliberal multiculturalism: the remaking of cultural rights and racial dominance in Central America." PoLAR: Political and Legal Anthropology Review 28 (1): 10-28.

IACHR (Inter-American Commission on Human Rights)

1985 "Resolution No. 12/85, Case No. 7615 (Brazil)." http://www.escr-net.org/sites/default/ files/ICHR_Report_No_12_85.html (accessed April 29, 2014).

2002 "Precautionary measures 2002 (Brazil)." http://www.cidh.org/medidas/2002.eng.htm (accessed April 29, 2014).

2009 "Report No. 98/09, Petition 4355-02 (Xucuru Indigenous People, Brazil), October 29, 2009." http://www.cidh.oas.org/annualrepeng/Brazil4355.02eng.htm (accessed April 29, 2014).

IBGE (Instituto Brasileiro de Geografia e Estatística)

2013 Atlas do Censo Demográfico 2010. Rio de Janeiro: IBGE.

ILO (International Labor Organization)

2014 "Ratifications of C169 - Indigenous and Tribal Peoples Convention, 1989 (No. 169)." http://www.ilo.org/dyn/normlex/en/f?p=NORMLEXPUB:11300:0::NO:11300:P11300_ INSTRUMENT_ID:312314:NO (accessed April 28, 2014). 
Jackson, Jean E. and Kay B. Warren

2005 "Indigenous movements in Latin America, 1992-2004: controversies, ironies, new directions." Annual Review of Anthropology 34: 549-573.

Laurie, Nina, Robert Andolina, and Sarah Radcliffe

2002 “The excluded 'indigenous'? The implications of multi-ethnic policies for water reform in Bolivia," pp. 252-276 in Rachel Sieder (ed.), Multiculturalism in Latin America: Indigenous Rights, Diversity, and Democracy. Hampshire, NY: Palgrave Macmillan.

Lima, Antonio Carlos de Souza

1998 “O governo dos índios sob a gestão do SPI," pp. 155-172 in Manuela Carneiro da Cunha (ed.), História dos Índios no Brasil. 2d edition. São Paulo: Companhia das Letras/Secretaria Municipal de Cultura, FAPESP.

Lima Jr., Jayme Benvenuto, Fabiana Gorenstein, and Leonardo Jun Ferreira Hidaka (eds.). 2003 Manual de direitos humanos internacionais: Acesso aos sistemas global e regional de proteção dos direitos humanos. São Paulo: Edições Loyola.

Melatti, Julio Cezar 2007 Índios do Brasil. São Paulo: Editora da Universidade de São Paulo.

Melo, Mario

2006 "Recent advances in the justiciability of indigenous rights in the Inter-American System of Human Rights." Sur: International Journal on Human Rights 4 (3): 31-49.

Mendes Júnior, João 1988 (1912) Os indigenas do Brazil, seus direitos individuaes e politicos. Facsimile edition. São Paulo: Typ. Hennies Irmãos.

Ministério da Justiça and SEDH (Secretaria de Estado dos Direitos Humanos)

2003 Medidas cautelares: Caso "Cacique Marquinhos Xucuru," segundo relatório do governo brasileiro. Brasília: SEDH.

Molinero, Natalia Álvarez

2006 "From the theory of discovery to the theory of recognition of indigenous rights: Conventional international law in search of homeopathy," pp. 165-181 in Saladín MeckledGarcía and Basak Çali (eds.), The Legalization of Human Rights: Multidisciplinary Perspectives on Human Rights and Human Rights Law. New York: Routledge.

Neto, Fernando da Costa Tourinho

1993 "Os direitos originários dos índios sobre as terras que ocupam e suas consequências jurídicas," pp. 9-43 in Juliana Santilli (ed.), Os Direitos Indígenas e a Constituição. Porto Alegre: Sérgio Antonio Fabris Editor.

Oliveira, João Pacheco de

1998 "Redimensionando a questão indígena no Brasil: uma etnografia das terras indígenas," pp. 15-42 in João Pacheco de Oliveira (ed.), Indigenismo e territorialização: Poderes, rotinas e saberes coloniais no Brasil contemporâneo. Rio de Janeiro: Contra Capa Livraria.

Oliveira, João Pacheco de and Alfredo Wagner Berna de Almeida

1998 "Demarcação e reafirmação étnica: um ensaio sobre a FUNAI," pp. 69-123 in João Pacheco de Oliveira (ed.), Indigenismo e territorialização: Poderes, rotinas e saberes coloniais no Brasil contemporâneo. Rio de Janeiro: Contra Capa Livraria.

Peña, Guillermo de la 2005 "Social and cultural policies toward indigenous peoples: perspectives from Latin America." Annual Review of Anthropology 34: 717-739.

Perrone-Moisés, Beatriz

1998 "Índios livres e índios escravos: os princípios da legislação indigenista do período colonial (séculos XVI a XVIII)," pp. 115-132 in Manuela Carneiro da Cunha (ed.), História dos Índios no Brasil. 2d edition. São Paulo: Companhia das Letras/Secretaria Municipal de Cultura, FAPESP.

Piovesan, Flávia

2004 "Direitos sociais, econômicos e culturais e direitos civis e políticos." Sur: Revista Internacional de Direitos Humanos 4 (3): 21-47.

Presidência da República

1996 Programa nacional de direitos humanos. Brasília: Presidência da República/Secretaria de Comunicação Social/Ministério da Justiça. 
Rabben, Linda

2004 Brazil's Indians and the Onslaught of Civilization: The Yanomami and Kayapó. Seattle and London: University of Washington Press.

Reis, Rossana Rocha

2013 "O Brasil e o sistema interamericano de direitos humanos: elementos para compreender a crise Belo Monte." Pensamiento Propio 38: 19-47.

Rodríguez-Garavito, César and Luis Carlos Arenas

2005 "Indigenous rights, transnational activism, and legal mobilization: the struggle of the U’Wa people in Colombia," pp. 241-266 in Boaventura de Sousa Santos and César RodríguezGaravito (eds.), Law and Globalization from Below: Towards a Cosmopolitan Legality. Cambridge: Cambridge University Press.

Santos, Boaventura de Sousa

2003 "O estado heterogéneo e o pluralismo jurídico," pp. 47-95 in Boaventura de Sousa Santos and João Carlos Trindade (eds.), Conflito e transformação social: Uma paisagem das justiças em Moçambique. Porto: Afrontamento.

2006 "The heterogeneous state and legal pluralism in Mozambique." Law and Society Review 40 (1): 39-75.

Santos, Cecília MacDowell

2007 "Transnational legal activism and the State: reflections on cases against Brazil in the InterAmerican Commission on Human Rights." Sur: International Journal on Human Rights 4 (7): 25-59.

Sieder, Rachel

2002 "Introduction," pp. 1-23 in Rachel Sieder (ed.), Multiculturalism in Latin America: Indigenous Rights, Diversity, and Democracy. Hampshire, NY: Palgrave Macmillan.

Silva, José Afonso da 1998 Curso de direito constitucional positivo. 15th edition. São Paulo: Malheiros Editores.

Stavenhagen, Rodolfo

2002 "Indigenous peoples and the state in Latin America: an ongoing debate," pp. 24-44 in Rachel Sieder (ed.), Multiculturalism in Latin America: Indigenous Rights, Diversity, and Democracy. Hampshire, NY: Palgrave Macmillan.

Van Cott, Donna Lee (ed.).

2002 Indigenous Peoples and Democracy in Latin America. New York: St. Martin's Press.

Warren, Jonathan $\mathrm{W}$.

2001 Racial Revolutions: Antiracism and Indian Resurgence in Brazil. Durham, NC, and London: Duke University Press. 